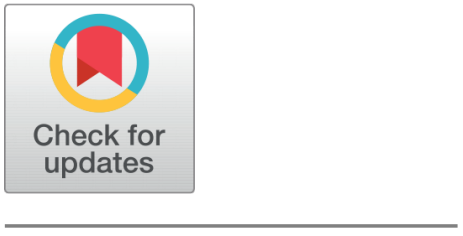

OPEN ACCESS

Received: 26-05-2020

Accepted: $30-07-2020$

Published: 27-08-2020

Editor: Dr. Natarajan Gajendran

Citation: Onwuachiiheagwara NP, Iheagwara IB (2020) The effect of minute chronic release of hydrocarbon on soils of communities in proximity to oil fields. Indian Journal of Science and Technology 13(31): 3141-3149. https://doi.org/ 10.17485/IJST/v13i31.713

*Corresponding author.

pniheagwara@gmail.com

Funding: None

Competing Interests: None

Copyright:

(c) 2020 Onwuachiiheagwara \& Iheagwara. This is an open access article distributed under the terms of the Creative Commons Attribution License, which permits unrestricted use, distribution, and reproduction in any medium, provided the original author and source are credited.

Published By Indian Society for Education and Environment (iSee)

ISSN

Print: 0974-6846

Electronic: 0974-5645

\section{The effect of minute chronic release of hydrocarbon on soils of communities in proximity to oil fields}

\author{
Nneka P Onwuachiiheagwara ${ }^{1 *}$, Ifeanyichukwu B Iheagwara ${ }^{2}$ \\ 1 Department of petroleum engineering, Delta State University, Nigeria \\ 2 Department of Biological Sciences, University of Ghana, Legion, Ghana
}

\section{Abstract}

Objective: The study documents the effects of hydrocarbon exploitation (without major oil spills) on soils of a rural community, $5 \mathrm{~km}$ from an E \&P (exploration \& production) site. Method/Statistical analysis: By 3 composite drill cuttings, 6 agricultural soil samples obtained from Oben oil field or oil mining lease 4 (OML 4) and Oben village, Nigeria were microbiologically examined. Water and crude oil samples were subjected to physical, chemical, and microbiological examinations. Pearson and Rosenberg model (1978) was used to describe changes in species richness and abundance from 2018 - 2008. The 2008 environmental impact assessment report (EIA) was the environmental baseline. Finding: Significant changes in microbe diversity and population was noticed from 2008 to 2018 although no oil spills occurred. Total heterotrophic bacterial count (TBC) revealed greater diversity in 2008 than in 2018. The average TBC for soil samples from rural community and E\&P site were $7.0 \pm 0.30 \times 106 \mathrm{cfu} / \mathrm{g}$, and $2.23 \pm 0.15 \times 102 \mathrm{cfu} / \mathrm{g}$, respectively, in contrast to $6.60 \times 109 \mathrm{cfu} / \mathrm{g}$ in 2008. Percentages of hydrocarbon utilizing microbes increased; indicative of a more favorable environment. Chi-square test (chi-square critical value $=9.49 \& p$-value $=0.05$ ) used to compare observed population data with the expected; showed changes were not random chance but due to E \&P activities. The prevailing regulatory approach was incapable of capturing fundamental issues of contemporary continuous, routine release of contaminants. Need to understand the subtle and pernicious effect of E\&P operations on neighboring communities. Environmental laws should be reexamined. Applications: Microbes can be used to monitor minute, chronic release of hydrocarbon, inexpensively. They are "markers" in environmental changes even before major pollution, contamination, spillage or devastation occurs.

Keywords: Acute contaminants on soils; contamination in nearby communities; oil field's contaminants; contamination by proximity; chronic pollutants 


\section{Introduction}

Microbes have been in existence for billions of years. They live in different environments. Their presence tells us much about the surrounding. They assist in degradation of pollutants and influence remediation of contaminated soils through complex metal-substrate-microbe interactions ${ }^{(1)}$. Their metabolic activities produce substances that can be used to map their existence and condition of the environment ${ }^{(2-4)}$. Their abundance and diversity therefore, are indicative of quality of environment; the more favorable the environment, the greater their population, (i.e. population density) ${ }^{(5-9)}$. Therefore, when condition changes, species of microbes, and their population densities change; this knowledge can be used to know minute changes in any site $e^{(10-12)}$. In this research, this hypothesis was tested.

Pollution is a consequence of industrialization. During manufacture of products, wastes are formed. When wastes accumulate; they cause pollution. Consequently, the environment is "degraded"; becomes less favorable to some microbes but more to others. This is because of change(s) in some chemical and physical parameter(s) in the soil or water. Approximately $80 \%$ of land mass worldwide is polluted by products of petroleum and or chemical ${ }^{(13)}$.

Oil pollution may be accidental and may occur during exploration, drilling, and transportation of crude oil or refined products. Environmental contamination with crude oil is worldwide. ${ }^{(14)}$ Recent examples of accidental pollution are the 03 December 1992, Aegean Sea tanker oil spill en route to Repsol refinery in A Coruña, Spain ${ }^{(15)}$, off the coast of Spain and the 17 April 1992 KATINA P tanker, while transiting the Mozambique channel ${ }^{(16)}$. Both were as a result of unexpected rough weather; spilling 74,000 and 66,700 metric tons of crude oil respectively. Oil spills may be deliberate, as in acts of illegal dumping of spent or used oil and in oil sabotage. ${ }^{(17)}$. Oil sabotage occurs when individuals deliberately destroy oil installation or pipelines for monetary, political or military advantage. This was illustrated in The 1991 Gulf War oil spill which spewed an estimated 8 million barrels of oil into the Persian Gulf. Early reports from Iraqi forces claimed spill had been caused by the United States sinking of two oil tankers. Others believe it was the result of Iraqi forces opening valves of oil wells and pipelines as they retreated from Kuwait, with the apparent strategic goal to foil potential landing by US Marines. ${ }^{(16)}$. Unrest in the society also leads to oil sabotage ${ }^{(18)}$.

Much has been documented on effect(s) of massive, enormous incidents of oil spills ${ }^{(19)}$. The implication of such incidents isn't in doubt. We do not seek to re-invent the wheel but rather to document effects of minute, chronic pollution on land. Media attention is riveted on large scale spills. Smaller incidents are often ignored and not reported. Minute but chronic spills are completely disregarded.

Prevailing regulatory approach is incapable of capturing fundamental issues of contemporary continuous, routine, low-dose exposures to contaminants that are within legally sanctioned limits ${ }^{(20)}$. This is more daunting in countries with weak intuitions where corruption is high and cost of litigation prohibitory ${ }^{(21)}$.

According to the business dictionary, oil spill are the presence of significantly large amount or layers of crude or refined oil on soil or sea water ${ }^{(22)}$. This definition is limiting and implies that only large volume of pollutant is detrimental to the environment. Investigation by Abdulazeez (2007) ${ }^{(23)}$ showed that pollutants are wide spread and due to "modern activities" of smoking cigarettes, fossil fuel burning, driving cars and use of fuels in industries. According to Frank Fischer (2000) ${ }^{(24)}$, minute chronic pollution are virtually undetectable without scientific investigation. Not much evidence exists on effects of minute chronic oil spills. It is proposed that small minute dose over time, affect not only the immediate environment (on which pollution occurs) but also environments in proximate to it. To study this, effect(s) of E \&P activities in Urhonigbe Forest Reserve, Edo State, Nigeria was considered ( Figure 1).

The Reserve is a natural low tropical rain forest preserved for decades but in 1972, a portion was excised out, due to its vast hydrocarbon deposit. It was later known as Oben oil field or oil mining lease 4 (OML 4). In this research, soil, water and crude oil samples from Oben oil field and neighbouring rural community, Oben village, were studied.

\section{Study area description}

Urhonigbe forest reserve ( $\left.5^{\circ} 56^{\prime} 17.52^{\prime \prime} ; 5^{\circ} 53^{\prime} 19.93^{\prime \prime}\right)$ lies within low tropical rain forest of Western Niger Delta Nigeria and is characterized by two prominent seasons, wet season (April- October) and dry season from November to March. In 1972, hydrocarbon was discovered in GPS $6^{\circ} 0^{\prime} 39 / 296^{\prime \prime}$ North, $5^{\circ} 52^{\prime} 3.718^{\prime \prime}$ East which covers a portion of the OML 4 and parts of Urhonigbe Forest Reserve showing River Jamieson, collection sites for the agricultural and composite soils and the pipeline reserve ${ }^{(25)}$.

Production started in 1974 and by 1985, oil production was in excess of 40 Mbopd with a total of 32 wells drilled that encountered hydrocarbon. Oben is approximately $50 \mathrm{ft}$ above mean sea level. Geologically, it lies in the Niger Delta basin. The Agbada, Akata and Benin formations chrono-stratigrahic units are identified in Quaternary sediment deposits. Hydro-geology consists of fine-medium grained sand aquifers (average thickness; $15 \mathrm{~m}$ ); clay deposits (3.5-9.0 m). Static ground water level is 
$13.21 \mathrm{~m}-14.53 \mathrm{~m}$. According to ${ }^{(25)}$,static water level is low and ground water is portable with low hydrocarbon concentration of less than $0.03 \mathrm{ppm}^{(25)}$.

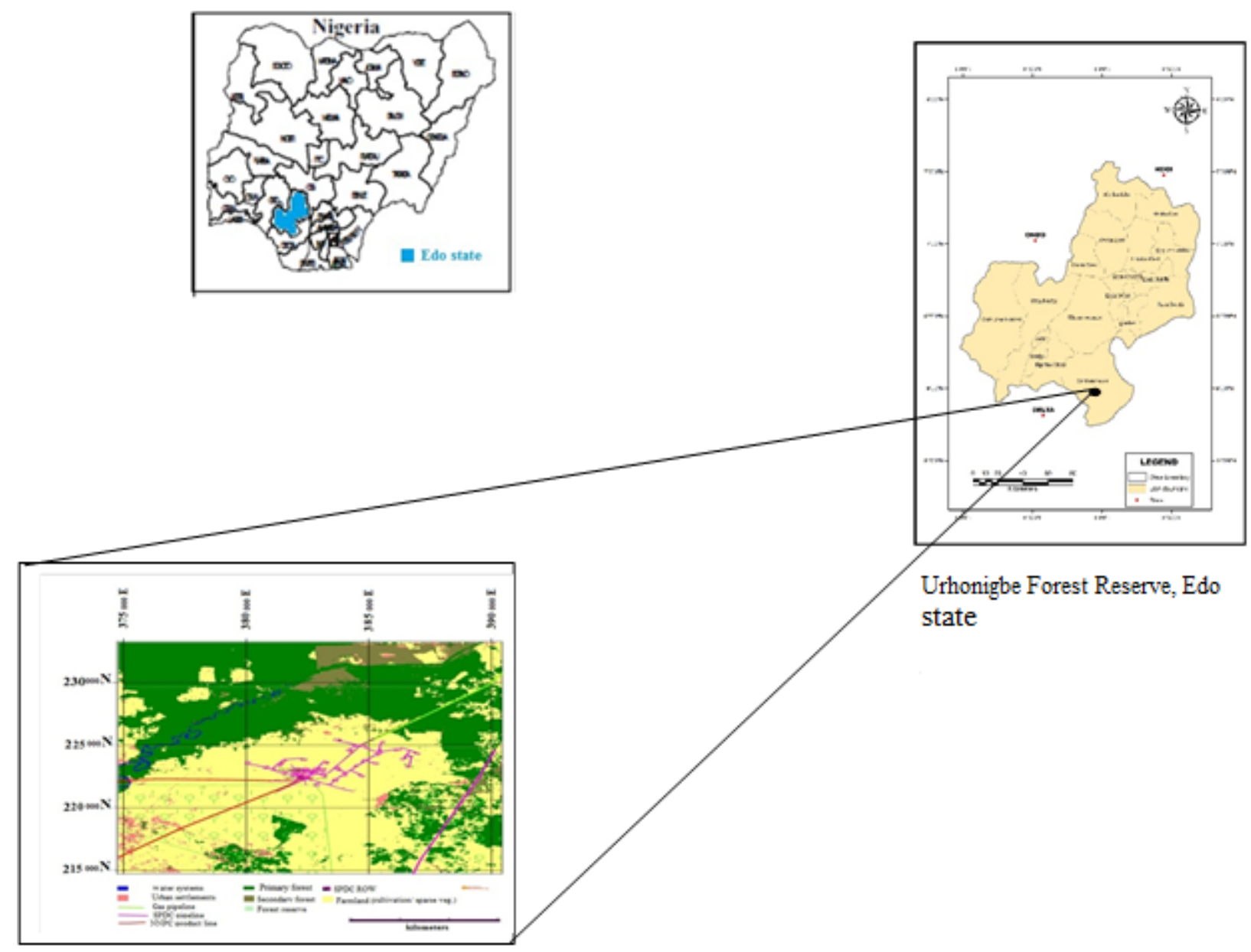

Fig 1. Map of Edo State, Nigeria, showing Urhonigbe Forest Reserve and OML 4. (Not drawn to scale)

\section{Material and methods}

It was proposed that environments in close proximity to oil drilling and production sites are negatively impacted and as a consequence, diversity of microbes in these places changes with time as petroleum activities take place proximate to them. Changes are believed to occur even without major oil spills. To test this, soil, composite drill cuttings, and water and crude oil samples were collected in 2018 from OML 4 and Oben village. These samples were analyzed in the University laboratory. Different methods are available to monitor natural and anthropogenic stress in organisms ${ }^{(26)}$. Pearson and Rosenberg model (1978) described changes in species richness, abundance and biomass ${ }^{(27)}$. An adaptation of Pearson and Rosenberg model was used and only changes in species richness and abundance were considered over a ten-year interval. This was done by comparing 2018 and 2008 microbiological data of the area. In 2008, an EIA was conducted in OML 4 and neighbouring village. The distance from sampling points in undisturbed sample sites to flow station in OML 4 is approximately $5 \mathrm{Km}$. All areas were originally in the Reserve and had the same geological and geographical settings and conditions prior to E\&P activities. Any post-exploration condition must be as a consequence of such activities.

Thus, data used were from two major sources. (1) Data from EIA conducted in 2008. Under Nigerian law, EIA must be carried out before any major construction that may have environmental consequences. Conditions at the reserve, as of 2008 were assumed to be the environmental baseline. (2) Another set of data source were obtained in 2018 during excursion into 
the Reserve. Comparative analyses of these two data sets would validate or reject the hypothesis, that environment in close proximity, to oil drilling and production sites are negatively impacted even without major oil spills.

\subsection{Collections of samples and data}

9 soil samples were collected and analyzed. This includes 3 composite hydrocarbon-contaminated soils (designated ObenHC 13) from OML 4 and 6 agricultural soils from Oben village designated UFR-1 -UFR-6. 2 water samples each were collected from River Jamieson (which transverses the Reserve) and a borrow pit in Oben village. Relationship between soil sample collections sites are shown in supplementary file. Soil collection sites were deliberately selected to approximate 2008 sampling points. Dark brown composite drill cuttings were collected from on-site surface dump site and preserved. Agricultural soils samples from Oben village were brown in color; slightly lighter in hue than composite drill cuttings. Soils samples were collected with sterile trowel at a depth of 10-15 cm from surface, after removal of organic debris and leaves associated with topsoil. Total weights of $4.00 \mathrm{~kg}$ of soil were collected from each site and preserved in sterile containers to prevent contamination. All soil samples were analyzed in the university's' laboratories for microbial activity in accordance with established guidelines and procedures ${ }^{(28)}$. Water samples were collected into sterile, transparent, glass jars with lids. Glass containers were earlier autoclaved at 121 degrees centigrade for 45 minutes.

\subsubsection{Examination of samples}

Samples were subjected to physical, chemical and microbiological examinations.

\subsubsection{Physical and chemical tests}

Several tests were undertaken as described by American Public Health Association, (APHA, 1989); ${ }^{(29)}$. The hydrogen ion concentration $(\mathrm{pH})$ measurements were with a beach top model 3505 Digital $\mathrm{pH}$ meter. Electrical Conductivity (EC) was measured in the 1:1 soil to water suspension after $\mathrm{pH}$ measurement using Model DDS-307 conductivity meter with an accuracy of $\pm 1.0 \%$. Results were expressed in micro-Siemens $(\mu \mathrm{S})$ per $\mathrm{cm}$. Dissolved oxygen (DO) measurement was with Dissolved oxygen meter 850081 DOK. The DO meter was also, used for TDS measurements with its additional probe. BOD was determined with h15421 dissolved oxygen and BOD bench top meter.

Soil texture was determined by visual examination, inspection and by grain size analysis. The sieve shaker (WQS vibrator) was used for grain size analysis. Udden ${ }^{(30)}$ and Wentworth ${ }^{(31)}$ classification with phi $0,1,2,3$ sizes 1,500 $\mu \mathrm{m}, 250,125$ which represented very coarse sand, coarse sand, medium sand and fine sand grain sizes scale were used.

\subsubsection{Microbiological analysis}

Microbiological analysis of samples included isolation, characterization and purification of isolates.

\subsubsection{Isolation, characterization and purification}

Isolation of bacteria and fungi in soil and water samples were by serial dilution and standard plate count. Cultures were purified following subculture of isolates into differential cum selective medium. $100 \mathrm{ml}$ stock of samples were prepared into $200 \mathrm{ml}$ flask and serially diluted into tubes of $9 \mathrm{ml}$ of distilled water, twice. One (01) milliliter of sample was plated onto nutrient agar supplemented with chloramphenicol for bacterial isolates and another with potato dextrose agar supplemented with fluconazole for fungal isolates. Plates were incubated for 24 hours at $28 \pm 2^{\circ} \mathrm{C}$.

Fungal cultures were incubated in a humidified environment in the laboratory for $48-72$ hours at $30^{\circ} \mathrm{C}$. Fungal isolates were characterized and identified following methods stipulated by Barnett and Hunter ${ }^{(32)}$. All isolates were counted and enumeration using the formula by Willey ${ }^{(33)}$. Using method described by Kayode-Isola et al.; $2008^{(34)}$ pure cultures were extracted. Biochemical tests were carried out on isolates.

$$
\text { Estimated population }=\frac{\text { Number of colonies } \times \text { dilution }}{\text { Volume of inoculums }}
$$

Bacterial isolates were sub-cultured using streak plate method and pure colonies obtained onto favorable media of mannitol salt agar, Bacillus media, eosin methylene blue agar, Pseudomonas cetrimide agar, bile esculin agar, Salmonella Shigella agar and Simon citrate agar. Isolates were gram stained, and other biochemical tests such as oxidase, catalase, and indole test were performed.

For identification of fungal isolates; isolates were stained with lactophenol blue and wet mounted. Fungal isolates were examined, under the microscope. Specialized structures such as hyphae and conidia were observed and were correlated with standard texts. 


\section{Results and discussion}

Soil, water and crude oil samples from OML 4 and Oben village were examined establish effect(s) hydrocarbon exploitation activities in OML 4 on Oben village. Microbiological analysis of samples revealed several microbes of significance in crude oil and soil samples ( Tables 1 and 2). From their characteristics, main fungal and bacterial isolates were identified. Diversity in crude oil samples was very limited. It is a harsh habitat for microbes ${ }^{(35)}$. This is probably due to its high toxicity and hydrophobicity. According to Latha and Kalaivani, (2012), presence of crude oil influences biodiversity and distribution of microorganisms in an environment ${ }^{(36)}$. Similar results was reported by Man et al. (2015) ${ }^{(37)}$ who found P. aeruginosa the most dominant bacterial isolate in crude oil samples from China. Survival and growth of $P$. aeruginosa suggests of its ability to utilize components of crude oil as an energy source. This interpretation is in agreement with similar reports in other parts of the world.

Table 1. Biochemical characteristics of isolates from crude oil samples

\begin{tabular}{|c|c|c|c|}
\hline \multicolumn{4}{|c|}{ Characteristics of fungal isolates } \\
\hline Cultural & & Black fluffy colonies with white edges & \\
\hline \multicolumn{4}{|l|}{ Microscopic } \\
\hline \multicolumn{2}{|l|}{ Nature of hyphae } & \multicolumn{2}{|l|}{ Septate } \\
\hline \multicolumn{2}{|l|}{ Type of spore } & \multicolumn{2}{|l|}{ Conidiospore } \\
\hline \multicolumn{2}{|l|}{ Colour of spore } & \multicolumn{2}{|l|}{ Brown } \\
\hline \multicolumn{2}{|l|}{ Appearance of special } & \multicolumn{2}{|l|}{ Foot cells } \\
\hline \multicolumn{2}{|l|}{ Isolate } & \multicolumn{2}{|l|}{ Aspergillus } \\
\hline \multicolumn{4}{|c|}{ Characteristics of bacterial isolates } \\
\hline \multicolumn{4}{|c|}{ Cultural } \\
\hline Elevation & Low convex & Low convex & Convex \\
\hline Margin & Entire & Smooth & Smooth \\
\hline Colour on MHA & Dark Cream & Cream & Cream \\
\hline \multicolumn{4}{|l|}{ Morphological } \\
\hline Gram stain & Negative & Positive & Positive \\
\hline Cell type & Rod & Rod & Cocci \\
\hline Arrangement & Single & Single & Chains \\
\hline Spore staining & ND & Positive & ND \\
\hline \multicolumn{4}{|l|}{ Biochemical } \\
\hline Catalase & Positive & Positive & Positive \\
\hline Indole & Negative & Negative & ND \\
\hline Citrate & Positive & Positive & ND \\
\hline Urease & Negative & Positive & ND \\
\hline Oxidase & Positive & Negative & ND \\
\hline Gr. Diff. Agar & PCA & BCA (Straw) & MSA, ORSAB \\
\hline Identity & Pseudomonas sp. & Bacillus sp. & Staphylococcus sp. \\
\hline
\end{tabular}

Key: Gr. Diff. Agar $=$ Growth on differential agar, PCA = Pseudomonas cetrimide agar, BCA (straw) = Straw colour on Bacillus cereus agar, MSA = Mannitol salt agar, ORSAB = Oxacillin resistant screening agar base

Table 2. Cultural, morphological and biochemical characterization of bacterial isolates from agricultural and composite soil samples

\begin{tabular}{|c|c|c|c|c|c|}
\hline Characteristics & A & $\mathrm{B}$ & $\mathrm{C}$ & $\mathrm{D}$ & $\mathrm{E}$ \\
\hline Shape & Round & Round & Spherical & Round & Spherical \\
\hline Colour & Pale green & Cream & Milky & Milky & Milky \\
\hline Margin & Entire & Rough & Entire & Entire & Entire \\
\hline Opacity & Translucent & Opaque & Opaque & Opaque & Opaque \\
\hline Elevation & Flat & Raised & Flat & Flat & Flat \\
\hline Wet/ Dry & Wet & Dry & Wet & Wet & Wet \\
\hline Grain stain & - & + & - & - & - \\
\hline Cell type & Rod & Rod & Rod & Curve & Rod \\
\hline Arrangement & Pair & Single & Single & Single & Single \\
\hline Catalase & - & + & + & + & + \\
\hline Bile esculin & - & - & - & - & - \\
\hline Oxidase & + & + & - & + & - \\
\hline
\end{tabular}

Continued on next page 


\begin{tabular}{|c|c|c|c|c|c|}
\hline \multicolumn{6}{|c|}{ Table 2 continued } \\
\hline Indole & + & - & + & - & - \\
\hline Urease & - & + & - & + & + \\
\hline Citrate & + & + & + & - & - \\
\hline Lactose & - & + & & + & + \\
\hline Sucrose & + & & - & + & + \\
\hline Maltose & + & & - & + & + \\
\hline Glucose & + & - & + & + & + \\
\hline VP & + & + & - & - & \\
\hline Mannitol & - & & + & - & + \\
\hline Spore & - & + & - & - & + \\
\hline Probable isolate & Pseudomonas sp. & Bacillus sp. & Escherichia sp. & Staphylococcus sp. & Bacillus sp. \\
\hline
\end{tabular}

\subsection{Agricultural soil samples and composite drill cutting samples}

Soil samples were separated into two broad categories; composite soil samples with drill cuttings and agricultural soil samples from the Reserve ( Table 3 ). Composite samples exhibited the less diversity (Pseudomonas sp., Bacillus sp.) and had an average microbial population of $2.01 \times 10^{2} \mathrm{cfu} / \mathrm{g}$ soil. Soil samples from the Reserve exhibited greater microbiological diversity (Bacillus sp., B. subtilis, Escherichia coli, Pseudomonas sp., and Staphylococcus sp.) with average population of $7.15 \mathrm{X} 10^{7} \mathrm{cfu} / \mathrm{g}$ soil.

Table 3. Total heterotrophicbacteria of soil samples and drilling cuttings from Oben Field (OML 4) and Oben village, Urhonigbe Forest Reserve

\begin{tabular}{|c|c|c|c|c|}
\hline \multicolumn{5}{|c|}{ Soil samples and drilling cuttings from Oben Field (OML 4) } \\
\hline $\mathrm{S} / \mathrm{N}$ & Sample no. & $\begin{array}{l}\text { Heterotrophic Count (cfu/g. } \\
\text { soil) }\end{array}$ & season & Predominant bacterial genera \\
\hline 1 & ObenHC 1 & $2.23 \times 102$ & dry & Pseudomonas aeruginosa, Bacillus subtilis. \\
\hline 2 & ObenHC 2 & $2.08 \times 102$ & dry & Pseudomonas aeruginosa, Bacillus subtilis. \\
\hline 3 & ObenHC 3 & $1.98 \times 102$ & dry & Pseudomonas aeruginosa, Bacillus subtilis. \\
\hline \multicolumn{5}{|c|}{ Soil samples from Oben village, Urhonigbe Forest Reserve } \\
\hline 4 & UFR-1 & $7.00 \times 107$ & dry & $\begin{array}{l}\text { Bacillus cereus, B. subtilis, Escherichia coli, Pseu- } \\
\text { domonas aeruginosa, and Staphylococcus aureus }\end{array}$ \\
\hline 5 & UFR-2 & $7.4 \times 107$ & dry & Bacillus cereus, B. subtilis, Staphylococcus aureus \\
\hline 6 & UFR-3 & $7.2 \times 107$ & dry & Pseudomonas aeruginosa, and Staphylococcus aureus \\
\hline 7 & UFR-4 & $7.3 \times 107$ & dry & Bacillus cereus, B. subtilis \\
\hline 8 & UFR-5 & $7.3 \times 107$ & dry & Pseudomonas aeruginosa, and Staphylococcus aureus \\
\hline 9 & UFR-6 & $6.7 \times 107$ & dry & Bacillus cereus, B. subtilis \\
\hline
\end{tabular}

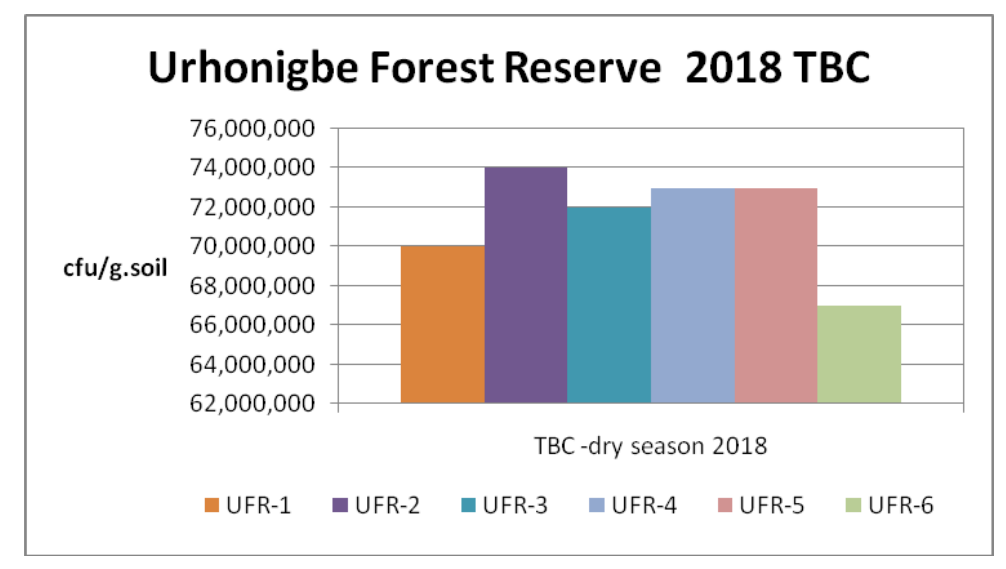

Fig 2. TBC in Urhonigbe Forest Reserve in 2018 
It was observed that despite the close proximity of Oben village to OML 4, bacterial diversity obviously was more in agricultural soil from Oben village then in samples from OML 4. Although both were originally part of the Reserve, and had similar values in 2008, 10 years of E \& P had changed the microbiological landscape in the two locations. It was surmised that during minute but chronic contamination (e.g. during drilling, transportation and other activities associated with the E \& P industry) in OML 4, microbial species unable to thrive in the changed environment were wiped off or stunt in their development. As a consequence; agricultural soil from the Reserve was home to more profuse diversity of microbes than OML 4. There was also, greater microbial diversity in 2008 than in 2018. Yilei et al. (2020), observed change in microbial community due to presence of crude oil in the soil ${ }^{(14)}$

The average HBCs for agricultural soil samples from Oben village, crude oil and composite samples from OML 4 were: $7.0 \pm 0.30 \times 10^{6} \mathrm{cfu} / \mathrm{g}, 3.25 \pm 1.35 \times 10^{2} \mathrm{cfu} / \mathrm{ml}$ and $2.23 \pm 0.15 \times 10^{2} \mathrm{cfu} / \mathrm{g}$, respectively. Agricultural soil samples from Oben village showed greater diversity than composite drilling cutting and soil samples from OML 4. (This is in contrast an average value of $6.60 \times 10^{9} \mathrm{cfu} / \mathrm{g}$ and microbes such as Bacillus spp., Staphylococcus spp, Cladosporium sp., Mucor, Aspergillus Niger sp. in $2008^{(25)}$ )

Microbial abundance and diversity are indicators of soils' health. Healthier soils are home to greater number of microbes. On the average, samples from OML 4 exhibit lower bacterial and fungal population compared to agricultural soils samples from Oben village. From historical data ${ }^{(25)}$, the Reserve was healthier in 2008 with its greater diversity as revealed by a comparison of 2008 and 2018 values. In 2018, bacterial isolates from Oben village, revealed Bacillus sp., Staphylococcus sp., Pseudomonas sp., as predominant isolates and predominant fungal isolate was Penicillium sp., which is significant. From River Jameison water samples, Mucor sp., Cladosporium sp and Candida sp. were observed. From OML 4, prominent isolates were Pseudomonas sp. and Bacillus sp. ( Table 3) and Aspergillus, Fusarium (fungal isolates). Pseudomonas sp. genera were one of the abundance and were isolated in soil and crude oil samples.

\subsubsection{Physical and chemical tests}

Soil texture at Oben was sandy to loamy sands with a soil $\mathrm{P}^{\mathrm{H}}$ of 4.40 . Subsurface materials were brownish top soil. Organic matter values were high and exchangeable cations low. From water samples, there were little observable changes. Average water surface temperatures were higher than in 2008. Temperatures were $31.0^{\circ} \mathrm{C}$ and $28.6^{\circ} \mathrm{C}$ for River Jameison and borrow pit, respectively ${ }^{(25)}$. This was considered insignificant as differences were $2.05^{\circ} \mathrm{C}$ and $1.97^{\circ} \mathrm{C}$, respectively. Average dissolved solids (TDS) and conductivity were much higher in 2018.

Soil microbes contribute significantly to recycle of nutrients and energy; hence microbiological evaluation of microbes in 2008 and 2018 is crucial. Results revealed significance changes in THC from 2008 to 2018. HBC revealed greater diversity in 2008. In 2008 Bacillus spp., Staphylococcus spp., Escherichia coli were more abundant in the dry season while Mucor, Penicillium sp. were more abundant during wet months. According to ${ }^{(25)}$, there was practically no hydrocarbon utilizing bacteria in most samples analyzed in 2008; in most cases count were zero. Maximum hydrocarbon utilizing bacterial count in 2008 occurred during the dry season and was $5.0 \times 10^{5} \mathrm{cfu} / \mathrm{g}$. soil. The hydrocarbon utilizing bacteria were Bacillus spp., Micrococcus spp., Klebsiella spp. However, in 2018, Klebsiella spp. was not detected in any samples. This could hint at critical changes in environmental condition not favourable to Klebsiella spp. It was also noted that samples with greatest TBC were from collection sites far from oilfield facilities ( Figure 2).

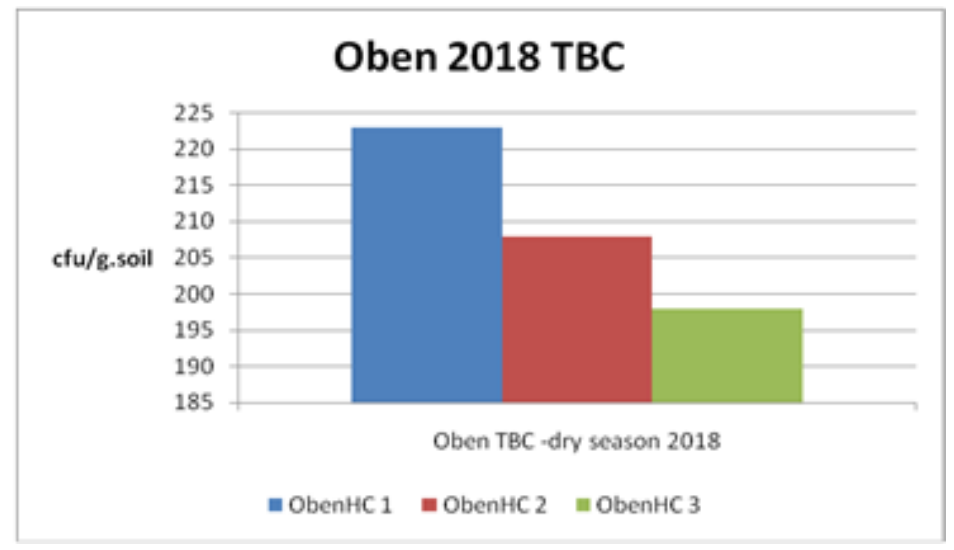

Fig 3. TBC in Oben sampling sites 
Samples from OML 4 exhibited lower TBC ( Figure 3). The stress (occasioned by introduction of hydrocarbon during drilling and production operations in OML 4 and consequent change in soil medium) simplify complex microbial community by elimination of more sensitive species and increase in number of tolerant microbes.

Microbes can be used as "markers" in environmental changes even before major pollution, contamination, spillage or devastation occurs. To validate this, two areas, OML 4 and Oben village were studied. OML 4 was carved out from the reserve; subjected to several years of petroleum explorations without major oil spillage, but effect(s) of hydrocarbon exploitation in OML 4 was evident in Oben Village, approximately $5 \mathrm{~km}$ away. Exploration and exploitation activities left "foot print" in Oben village and parts of the Reserve.

\subsubsection{Statistical analysis}

To determine categorical relationship between the two years (2008 and 2018) chi-square test was used. It compared observed population data with expected. It determines if changes were random chance variation or due to exploration/ exploitation activities. The expected value of $2.11 \times 10^{7} \mathrm{cfu} / \mathrm{g}$. soil (average of dry season 2008) was used, with chi-square critical value of 9.49 and p-value of 0.05. Chi-square distribution and critical value were to accept or reject our hypothesis. It revealed observed frequency differed significantly from expected.

\section{Conclusion}

Subtle reduction in population and diversity in species over time were observed. In 2008, hydrocarbon utilizing bacteria were very in low proportion of TBC. They varied from nil to $5.0 \%$ during the dry season. By 2018 , counts were higher and overall microbial diversity reduced. However, further research must be done to pinpoint culprits but exploration activities must be suspected $^{(38-40)}$. Fungal isolates, Fusarium, Penicillium, and Aspergillus were identified in samples and are effective in heavy metal contamination treatment and remediation. Their increased presence may indicate contamination.

\section{Acknowledgments}

The authors wish to acknowledge assistance from Delta State University laboratory staff in procurement of reagents and equipment.

\section{Declaration of interest statement}

The authors declare that there is no conflict of interest.

\section{References}

1) Tachibana S, Hidayat A. Biodegradation of Aliphatic Hydrocarbon in Three Types of Crude Oil by Fusarium sp. F092 under Stress with Artificial Sea Water. Journal of Environmental Science and Technology. 2012;5(1):64-73. Available from: https://dx.doi.org/10.3923/jest.2012.64.73.

2) Ojewumi ME, Okeniyi JO, Ikotun JO, Okeniyi ET, Ejemen VA, Popoola API. Bioremediation: Data on Pseudomonas aeruginosa effects on the bioremediation of crude oil polluted soil. Data in Brief. 2018;19:101-113. Available from: https://dx.doi.org/10.1016/j.dib.2018.04.102.

3) Islam NN, Islam KN, Akbar T, Akther F. Characterization and Confirmation of Lactobacillus spp. from Selective Regional Yoghurts for Probiotic and Interference with Pathogenic Bacterial Growth. Asian Journal of Biological Sciences. 2016;9(1):1-9. Available from: https://dx.doi.org/10.3923/ajbs.2016. 1.9 .

4) Abbas MFA, Bhola MS, Spear RJ, Olson LD, Mishra B. The shielding effect of wild type iron reducing bacterial flora on the corrosion of linepipe steel. Engineering Failure Analysis. 2013;33:222-235. Available from: https://dx.doi.org/10.1016/j.engfailanal.2013.05.020.

5) Lim MW, Lau EVA. Comprehensive guide of remediation technologies for oil contaminated soil - Present works and future directions. Marine Pollution Bulletin. 2016;109(1). Available from: https://doi.org/10.1016/j.marpolbul.2016.04.023.

6) Lin J, Ballim R. Biocorrosion control: Current strategies and promising alternatives. African Journal of Biotechnology. 2012;11(91):15736-15747. Available from: https://www.researchgate.net/publication/235921352_Biocorrosion_control_Current_strategies_and_promising_alternatives.

7) Marchak M. Logging the Globe. and others, editor;McGill-Queen's University Press. 1995.

8) Garrelfs DE, Garrelfs J. Corrosion of iron by sulfate-reducing bacteria-new views of an old problem. Applied Environmental Microbiology. 1226;80(4):12261236. Available from: https://doi.org/10.1128/AEM.02848-13.

9) Nwaugo VO, Onyeagba RA, Azu N, Nworie O. Petroleum produced formation water induced changes in bacterial quality and soil enzymatic activities in a farmland in Egbema Southern Nigeria. Estudos de Biologia. 2007;29(66). Available from: https://dx.doi.org/10.7213/reb.v29i66.22751.

10) Enning D, Venzlaff H, Garrelfs J, Dinh TH, Meyer V, Mayrhofer K, et al. Marine sulfate-reducing bacteria cause serious corrosion of iron under electroconductive biogenic mineral crust. Environmental Microbiology. 2012;14(7):1772-1787. Available from: https://dx.doi.org/10.1111/j.1462-2920. 2012.02778.x.

11) Corbett W. The future of bridge coating: A national qualification system for structural steel coatings. Journal of Protective Coating and Linings. $2004 ; 14$.

12) Stephenson M. A survey of produced water studies;vol. 46. Ray JP, Englehart FR, editors;New York.. Plenum Press. 1992.

13) Marinescu M, Toti M, Tanase V, Plopeanu G, Calciu I. The effect of crude oil pollution on physical and chemical characteristics of soil. Research journal of agricultural science. 2001;4(3):125-129. Available from: https://pdfs.semanticscholar.org/d847/3f3404876ac91780118fff9fc56ccaf70bcf.pdf. 
14) Yu Y, Zhang Y, Zhao N, Guo J, Xu W, Ma M, et al. Remediation of Crude Oil-Polluted Soil by the Bacterial Rhizosphere Community of Suaeda Salsa Revealed by $16 \mathrm{~S}$ rRNA Genes. International Journal of Environmental Research and Public Health. 2020;17(5). Available from: https://dx.doi.org/10.3390/ ijerph17051471.

15) Aegean Sea tanker oil spill. . Available from: https://en.wikipedia.org/wiki/Aegean_Sea_tanker_oil_spillDate.

16) P K. Off Mozambique. 1992. Available from: https://www.itopf.org/in-action/case-studies/case-study/katina-p-off-mozambique-1992/Date.

17) Bejarano A, Michael J. Large-scale risk assessment of polycyclic aromatic hydrocarbon in the shoreline sediments from Saudi Arabia: Environmental legacy after twelve years of the Gulf War oil spill. Environmental pollution. 2010;p. 1561-1569. Available from: https://www.sciencedirect.com/science/ article/abs/pii/S0269749109006277.

18) Albert NO, Amaratunga D, Haigh PR. Evaluation of the Impacts of Oil Spill Disaster on Communities and Its Influence on Restiveness in Niger Delta, Nigeria. Procedia Engineering. 2018;212:1054-1061. Available from: https://dx.doi.org/10.1016/j.proeng.2018.01.136.

19) Watts M, curse of black gold: 50 years of oil in the Niger Delta. Sweet and Sour: The Curse of oil in the Niger Delta. and others, editor;Power House Books. 2008.

20) Dayna N, Scott. .

21) Briggs D. Environmental pollution and the global burden of disease. British Medical Bulletin. 2003;68(1):1-24. Available from: https://dx.doi.org/10. 1093/bmb/ldg019.

22) Business dictionary . 2014. Available from: http://www.businessdictionary.com/definition/oil-spill.html.

23) Lawal TA. Polycyclic aromatic hydrocarbons. A review. Cogent Environmental Science. 2017;3(1). Available from: https://dx.doi.org/10.1080/23311843. 2017.1339841.

24) Fischer F. Citizen, Experts, and the environment: The politic of local knowledge Durham. North Carolina. Duke University Press. 2000.

25) Shell. Environmental Impact Assessment (EIA) of Oben Gas Development Project. . 2008. Available from: https://www.scribd.com/document/367257205/ Oben-Projects-EIA-Report.

26) Gesteira JLG, Dauvin JC. Impact of the Aegean Sea oil spill on the subtidal fine sand macrobenthic community of the Ares-Betanzos Ria (Northwest Spain). Marine Environmental Research. 2005;60(3):289-316. Available from: https://dx.doi.org/10.1016/j.marenvres.2004.11.001.

27) Pearson TH, Rosenberg R. Macrobenthic succession in relation to organic enrichment and pollution of the marine environment. Oceanography and Marine Biology Annual Review. 1978;16:229-311.

28) Ugbe F. Environmental Groundwater monitoring of James creek Field. Research Journal of Environmental and Earth Sciences. 2012;4(5):570-575. Available from: https://agris.fao.org/agris-search/search.do?recordID=AV2012089959.

29) APHA, American Public Health Association. Standard Methods for the Examination of Water and wastewater. 17th ed. Washington DC. American Public Health Association. 1989. Available from: http://hdl.handle.net/1969.3/24401.

30) Udden JA. Mechanical composition of clastic sediments. Geological Society of America Bulletin. 1914;25(1):655-744. Available from: https://dx.doi.org/ 10.1130/gsab-25-655.

31) Wentworth KC. A Scale of Grade and Class Terms for Clastic Sediments. The Journal of Geology. 1922;30(5):377-392. Available from: https: //dx.doi.org/10.1086/622910.

32) Barnett HL, Hunter B. Illustrated genera of imperfect fungi. 3rd ed. and others, editor;Burgess Pub. 1986.

33) Willey LM, Sherwood LJ, Woolverton L. Microbiology. 7th ed. New York. Mc-Graw Hill. 2008.

34) Kayode-Isola TM, Eniola KIT, Olayemi A, Igunnugbemi OO. Response of Resident Bacteria of a Crude Oil-Polluted River to Diesel Oil. AmericanEurasian Journal of Agronomy. 2008;1(1):6-9. Available from: https://www.semanticscholar.org/paper/Response-of-Resident-Bacteria-of-a-CrudeRiver-to-Kayode-Isola-Eniola/7f750576f6472951298f90b2fb354ala850cfa73.

35) Kryachko Y, Dong X, Sensen WC, Voordouw G. Compositions of microbial communities associated with oil and water in a mesothermic oil field. Antonie van Leeuwenhoek. 2012;101(3):493-506. Available from: https://dx.doi.org/10.1007/s10482-011-9658-y.

36) Latha R, Kalaivani R. Bacterial degradation of crude oil by gravimetric analysis. Advances in Applied Science Research. 2012;3(5):2789-2795. Available from: https://www.imedpub.com/articles/bacterial-degradation-of-crude-oil-by-gravimetric-analysis.pdf.

37) Cai M, Nie Y, Chi CQ, Tang YQ, Li Y, Wang XB, et al. Crude oil as a microbial seed bank with unexpected functional potentials. Scientific Reports. 2015;5(1):20-20. Available from: https://dx.doi.org/10.1038/srep16057.

38) Ogbulie TE, Nwaokorie FO. Molecular Diversity of Microbes with Probable Degradative Genes in Agricultural Soil Contaminated with Bonny Light Crude Oil. Journal of Ecosystem \& Ecography. 2016;01(s5). Available from: https://dx.doi.org/10.4172/2157-7625.s5-002.

39) Okoh AI, Trejo-Hernandez MR. Remediation of petroleum polluted systems: exploiting the bioremediation strategies. African Journal Biotechnology. 2006;5:2520-2525. Available from: https://www.ajol.info/index.php/ajb/article/view/56067.

40) Philip JC, Atlas RM. Bioremediation: Applied Microbial Solution for Real-World Environmental Clean Up. Atlas RM, Jim CP, editors;Washington DC. ASM Press. 2005. Available from: https://www.wiley.com/en-tm/Bioremediation\%3A+Applied+Microbial+Solutions+for+Real+ World+Environmental+Cleanup-p-9781555812393. 